\title{
TUDOMÁNYTÖRTÉNET
}

\section{Centenáriumi emlékezés Deme Lászlóra, a dialektológusra*}

DEME LÁSZLÓ dialektológiai munkássága két okból is kevéssé ismert a mai magyar nyelvésztársadalom tagjainak a többsége előtt. Egyrészt azért, mert dialektológiát müvelö szakember korábban is kevés volt nálunk, s ez ma sincs másként. Tehát kevesen vannak, kik DEME vonatkozó tevékenységének érdemi szakmai megítélésére nyugodt lélekkel vállalkozhatnak. Másrészt azért, mert DEME tudományos pályafutásának csupán első, rövidebb szakaszában foglalkozott intenzíven, a tudományágat alakító módon dialektológiával, második, hosszabb részében már nem. Főként a fiatalabb nemzedék tagjai tehát nemigen ismerik Deme László dialektológiai munkásságának legfontosabb eredményeit sem. (DEME az 1975-ös elméleti-módszertani atlaszkötet munkatársaként írta meg utolsó nagyobb dialektológiai tanulmányát.)

A tudománytörténeti tényeknél maradva: DEME LÁSzLÓ 1941-ben egyetemi hallgatóként jegyzi első tanulmányát a Magyar Nyelvben, s később több, nyelvtörténeti és nyelvjárástani tanulmányt is közzétett. Úgy, hogy a szóföldrajz tényeit bevonta nyelvtörténeti érveléseibe. Hamarosan azonban a dialektológia lett fő kutatási területévé. Mai szemmel nézve is feltünik azonban a pályakezdő DEME LÁSzLÓ széles körü érdeklődése, cikkeinek tematikai változatossága, tanulságok levonására, általánosítások megfogalmazására való hajlama.

Kijelenthető, hogy a gyorsan fölfelé ívelő dialektológusi tevékenység DEME LÁSZLÓ életmüvében a legfontosabbak közé tartozik. Az bizonyos, hogy ő volt nemzedékének ötletekben leggazdagabb, leginvenciózusabb magyar leíró dialektológusa. Ha pedig ez így van, akkor abban neki nyomatékos szerepe volt, hogy a Nyelvtudományi Intézetben az atlasz munkatársai a legnagyobb presztízsüek voltak (vö. ,,az ötvenes években vitathatatlanul a magyar nyelvészet és azon belül is a nyelvatlasz munkatársai rendelkeztek a legnagyobb belső presztízzsel az intézetben”: SzÉPE 2001: 12).

DEME LÁSZLÓ dialektológiai tevékenysége szorosan összefonódott A magyar nyelvjárások atlaszának (röviden: a nagyatlasznak) a munkálataival. DEME kezdettől fogva mindvégig ott van: a tervezés fázisában, az elökészítés idején, az anyaggyüjtésben (beleértve az ellenőrző gyüjtéseket is) és a szerkesztésben. Közben két kitünő monográfiát is megír: A magyar nyelvjárások néhány kérdése (1953) és kandidátusi disszertációként a Nyelvatlaszunk funkciója és további problémái (1956) címüt - s társszerzője A magyar nyelvatlasz munkamódszere (BÁRCZI szerk.1955) című munkának is. A következő kortárs-idézetek önmagukért beszélnek. BÁRCZI GÉZA szerint DEME ,jó ötleteivel igen hasznos segítője volt munkánknak”, továbbá: „Éles problémalátás, nagy ötletesség, józan kritika, az anyagon való fölényes uralkodás jellemzi” (in: DEME 1956: 318). IMRE SAMU sem rejtette véka alá elismerő véleményét: „Mind elméleti, mind módszertani tekintetben egyik legkiválóbb

*Az írás KIss 2012 nyomán készült.

DOI: https://doi.org/10.18349/MagyarNyelv.2021.2.199 
terméke az utóbbi évek dialektológiai kutatásainak DEME LÁSZLÓnak ... »A magyar nyelvjárások néhány kérdése«... címü munkája”, illetőleg „vizsgálatai során a magyar nyelvjárások minden lényegesebb problémáját érinti. DEME LÁSZLÓ két munkájából tanulmányom elkészítéséhez magam is sok indítékot kaptam” (1971: 32).

A nagyatlasz gyüjtőmunkálatai 1949-től 1964-ig tartottak, ebből az ellenőrző gyüjtések 1960 és 1964 között voltak. DEME az utóbbi szakasznak is aktív résztvevője volt (ez utóbbiban már magnetofonos felvételek is készültek!). Részt vett a szomszédos országok kutatópontjai egy részének a gyüjtésében is. Mintegy 370 településen gyüjtött! Ez alapján bizton állítható, hogy ő (is) alaposan ismerte a magyar nyelv területi változatosságát, a nyelvjárási beszélők szemlélet- és gondolatvilágát, hétköznapjaikat, s ami hangsúlyozandó, az éppen akkor, a téeszesítés nyomában bekövetkezett társadalmi-technológiai változásokat és a parasztság identitástudatában bekövetkezett negatív folyamatokat. Ezek a gyüjtések számára is rengeteg tapasztalattal jártak. A gyüjtők megismerkedtek a Kárpátmedencei magyar nyelvjárásokkal, a nyelvjárási beszélőkkel és az akkori magyar vidék életébe is bepillantást nyertek.

A nagyatlasz-munkálatokban szerzett tapasztalatok nagy jelentőségüek voltak, ugyanis szemléletváltozást hoztak a magyar dialektológiában, s hozzájárultak a szociolingvisztika iránti érzékenység növeléséhez. A statikus szemléletet ekkor váltotta fel a dinamikus. Megindult a változásvizsgálat, a figyelem egyre határozottabban fordult a társadalmi háttér változásainak és a regionális nyelvhasználat módosulásainak az összefüggésére. A hagyományos falusi nyelvhasználat gyökeres változásáról először DEMÉék adtak tudományosan igazolt tájékoztatást! DEME terepmunkai tapasztalatok alapján immár klasszikusnak tekinthető tanulmányokban szólt erről a jelenségről: a falvak lakóinak kettősnyelvűvé válásáról (arról tehát, hogy a nyelvjárási beszélők nyelvjárásuk mellett egyre inkább képesek voltak köznyelviesen is beszélni). Ezt írta például: „Mikor a gyüjtést kezdtük [...] Az idegennel szemben használt köznyelvi beszéd a legtöbb embernél még szerepjátszás volt [...]. Ma a köznyelvies beszéd idegenek elött egyre többekben reflex" (1964: 71). Új kutatási ág nőtt ki az atlaszmunkálatok tapasztalataiból: a regionális köznyelviség kutatása. DEME ebben is ötletadó és elméleti szintetizáló volt: az egész magyar beszélt nyelvi tartomány szét- és átrendeződéséröl, szét- és átrétegződéséről és társadalmi hátteréről írt 1973-ban a Magyar Nyelvben, úgy, hogy a köznyelvi kiejtési norma kérdését sem veszítette szem elöl.

De nem fetisizálta sem a regionális köznyelviséget, sem a köznyelvi kiejtési normát. Idézetek sora hozható tőle, bizonyságul arra, hogy világos, határozott, megfontolt véleménye volt az éppen időszerü és vitatott kérdésekről. Néhány példa szemléltetésképpen egyik konferenciai zárszavából: „Számunkra a hagyományos, klasszikus nyelvjárási rendszer és a köznyelvi az a két fix pont, amelyek között a változás megfogható” (1998: 326; utalásként arra a módszertani hibára, hogy valaki „csak” a regionális köznyelvet akarja vizsgálni egy-egy településen); „nem szeretek »regionális köznyelv«-ről beszélni, mert olyan aztán végképp nincs, de még »regionális köznyelvek«-ről sem, csak „regionális köznyelviség"-ről, mint egyfajta nyelvhasználati formáról, amit nagyon is mozgó és átmeneti formának érzek" (1998: 327; állást foglalt, mert nem volt pontosan definiálva a fogalom). „Ne higgyük, hogy a magnetofon olyan csodaszer, amellyel megoldódik a spontán beszéd rögzítése" (1998: 328; a magnetofonhoz kapcsolódó és a használók 
körében jelentkező euforikus illúziók ellen érvelt); „érdemes ismerni és megbecsülni az eddigi eredményeket” (1998: 329; az elödök eredményeinek nem ismeretét, figyelmen kívül hagyását számos esetben kifogásolta); „,nem azt kell elsősorban keresni az atlaszban, ami nincsen benne, hanem azt inkább, ami belekerülhetett" (DEME-IMRE 1975: 119; utalás arra, hogy egyesek olyasmiket hiányoltak az atlaszból, amik az atlasz tervezése idején még nem szerepeltek szempontként a dialektológiában).

Rejtély, miért nem folytatódott DEME lendületes és széles körü dialektológiai tevékenysége a nagyatlasz elkészülte után. Akinek oly sok ismerete és tapasztalata volt a magyar nyelvjárásokról és a nyelvatlaszok problémaköréről, predestinálva lett volna arra, hogy az atlasz „megszólaltatásában”, felhasználásában, értékesítésében is maradandót alkosson. Mint igazi kutató típusú nyelvészt, nyilván őt is vonzották az új feladatok, kihívások, az új munkaterületek. Ez lehet az egyik ok. De ez biztosan nem elegendő magyarázat. Sajnálom, hogy nem kérdeztem meg tőle, miért hagyta abba dialektológiai kutatómunkáját. Valahogy úgy éreztem, tapintatlanság lett volna ezzel a kérdéssel hozzá fordulnom. Utolsó telefonbeszélgetésünk végképp nem kínált lehetőséget a kérdés föltevésére. Magáról beszélt, szomorúan, lemondóan. Mintha búcsúzni készült volna... Úgy gondolom azonban, hogy a remélt hivatalos szakmai elismerés hiányának is szerepe lehetett dialektológiai kutatómunkájának abbahagyásában. Ebben a vélekedésben a DEMÉt jól ismerő s a közelmúltban elhunyt BALOGH LAJOS visszaemlékezése is megerősített. BENKÖ LORÁND és IMRE SAMU akadémikusok kétszer is javasolták az akadémiai levelező tagságra. Egyik esetben sem szavazta meg öt az Akadémia Nyelv- és Irodalomtudományok (I.) Osztálya.

Annak azonban később is, mindvégig számos jelét adta, hogy a dialektológia közel maradt szívéhez. Rendszeresen részt vett a szombathelyi dialektológiai szimpóziumokon, igaz, plenáris előadást nem vállalt. Zárszavak elmondására, hozzászólások megfogalmazására, bevezetők írására azonban szívesen vállalkozott. Sőt, az 1993-ban, a budapesti nemzetközi dialektológiai kongresszuson - angol nyelvű előadásban - tekintette át a magyar dialektológia történetét. Mindegyik említett megnyilatkozása tanulságos, mindegyik méltó az olvasásra és megszívlelésre ma is. A kongresszusi előadásban a hagyományőrzés és a korszerüsítés egyként való fontosságára utalva így fogalmazta meg optimista véleményét: „dialektológiánk ma a legkülönfélébb nyelvészeti módszereknek olyan átfogó és magas szintű együttese, ami a termékeny múltban gyökerezik, és a gyümölcsöt hozó jövőbe mutat" (1997: 49). 1992-ben jogos büszkeséggel, egyszersmind megnyugvással mondta: „Tanítványok, követők, vagy legalább a problémáktól megérintettek, mégiscsak a mi nemzedékünk müködésének eredményeként születtek” (1998: 325). A 2007. évi szombathelyi dialektológiai konferencián nem tudott már részt venni. A résztvevőknek azonban elküldte írásba foglalt üdvözletét. S ebben egyebek mellett ez áll: „,nosztalgikus érzésekkel forgatom most [a korábbi konferencia-köteteket]. Személyesen részt venni nem tudok már. De ott voltam az elsőn [...] 64 évvel ezelött, a mezőny Benjaminjaként [...]. Most, Benjaminból doyenné vénülve, kívánok hasznos munkát, eredményes folytatást kinekkinek, aki fontosnak érzi anyanyelvünknek, ember voltunk termékének, hordozójának és átörökítőjének minél többoldalú tanulmányozását, gondozását” (2007: 6-7).

A Magyar Nyelvben méltó módon BÉKÉSI IMRE búcsúztatta (2011). Nekrológjának címe nemcsak azért találó, mert DEME tevékenységét kitünően jellemzi, hanem mert a rá 
oly jellemző szószerkezetekkel is sikerült megidéznie mesterét, „A társadalom nyelviségének és a nyelviség társadalmának fáradhatatlan búvárá"-t. Akinek a magyar dialektológia is sokat köszönhet.

\section{Hivatkozott irodalom}

BÁRCZI GÉZA szerk. 1955. A magyar nyelvatlasz munkamódszere. Tanulmánygyüjtemény. Akadémiai Kiadó, Budapest.

BÉKÉSI IMRE 2011. A társadalom nyelviségének és a nyelviség társadalmának fáradhatatlan búvára. Magyar Nyelv 107: 368-375.

DEME LÁszLó 1953. A magyar nyelvjárások néhány kérdése. Nyelvtudományi Értekezések 3. Akadémiai Kiadó, Budapest.

Deme LÁszLó 1956. Nyelvatlaszunk funkciója és további problémái. Akadémiai Kiadó, Budapest.

DEME LÁSzLÓ 1964. Gondolatok nyelvatlasz-ellenőrzés közben. Nyelvtudományi Értekezések 40: 66-72.

DEME LÁszló 1997. A magyar dialektológia útja. In: BÜKY LÁszló szerk., Nyíri Antal kilencvenéves. József Attila Tudományegyetem Bölcsészettudományi Kar Magyar Nyelvészeti Tanszék, 37-49.

Deme LÁSzLó 1998. Vissza- és előretekintés. In: III. Dialektológiai szimpozion. Szerk. SzABÓ GÉZA, MolnÁR Zoltán. A Berzsenyi Dániel Tanárképző Főiskola Magyar Nyelvészeti Tanszékének Kiadványai II. Szombathely. 324-332.

Deme LÁszló 2007. Üdvözlet a folytatóknak! In: GutTMAnN MikLós, MolnÁR ZolTÁN szerk., V. Dialektológiai szimpozion. A Berzsenyi Dániel Főiskola Magyar Nyelvészeti Tanszékének Kiadványai VIII. Szombathely. 6-7.

DEME LÁSZLÓ - IMRE SAMU szerk. 1975. A magyar nyelvjárások atlaszának elméleti-módszertani kérdései. Akadémiai Kiadó, Budapest.

IMRE SAMU 1971. A mai magyar nyelvjárások rendszere. Akadémiai Kiadó, Budapest.

KISS JENŐ 2012. A dialektológus Deme Lászlóról. In: WACHA szerk. 2012: 29-33.

Mikola TiBor 1980-1981. Deme László köszöntése. Néprajz és Nyelvtudomány 24-25: 7-12.

SZABÓ JózSEF 1992. Deme László hetvenéves. Magyar Nyelvőr 116: 245-247.

SZÉPE GYÖRGY 2001. Több évtized az Intézetben... In: ANDOR JÓzSEF, SZÜTS TIBOR, TERTS IsTVÁN szerk., Szines eszmék nem alszanak... Szépe György 70. születésnapjára. Pécs, Lingua Franca Csoport. 1: 11-20.

WACHA IMRE szerk. 2012. Diófát ültetek, nem magamnak, hanem a késő utókornak. Emlékkötet Deme László nyelvészprofesszor tiszteletére. Kazinczy Ferenc Gimnázium, Győr. ${ }^{1}$

KISS JENÖ

ELTE Eötvös Loránd Tudományegyetem

${ }^{1}$ A kötet második, részben átdolgozott kiadása 2021-ben jelent meg: „Diófát ültetek...” Deme László emlékezete. Szerk. KovÁTs DÁnIEl és VÁsÁRhelYi ZsuzsanNA. Kiadta az Anyanyelvápolók Szövetsége és a győri Kazinczy Ferenc Gimnázium Az Iskoláért és az Anyanyelvért Alapítványa, Győr. 